\title{
The Most Important Buddhist Cultural Monuments In Tourism
}

\author{
Zebuniso Alimardonova
Lecturer At The Department of History Of Uzbekistan And Source Studies Termez State University,
Applicant For International University Termez State University,
Applicant For International University
Silk Road Tourism, Uzbekistan

Sik Road Tourism, Uzbekistan

\section{G OPEN ACCESS \\ The American Journal of Applied Sciences}

JULY 2020

Page No.: 76-85

Volume-II Issue-VII

PUBLISHED: 30 JULY 2020

www.usajournalshub.com/inde

x.php/tajas

Copyright: Original content

from this work may be used

under the terms of the

Creative Commons Attribution

4.0 licence.

\section{Abstract}

This article provides information on 9 archaeological Buddhist monuments in the Surkhandarya region, which have a two-thousand-year history and today are widely used for tourism purposes, as well as the penetration of one of the world religions - Buddhism into Central Asia, in particular, into ancient Bactria, its impact on the life and worldview of the local population, the formation of Buddhism as the leading religion of the Kushan Empire, subsequent geography of Buddhism and its spread to eastern countries.

Keywords: Ancient Bactria, Buddhism, Kushan Empire, Karatepa, Ayritom, Fayoztepa, Zurmala, Dalvarzintepa, Kholchayon, Kampyrtepa, Zartepa, Chingiztepa.

\section{Introduction}

In ancient times, the territory of the present Surkhandarya region, together with southwestern Tajikistan and northern Afghanistan, was part of Ancient Bactria.The convenient geographical position and natural conditions of this region have attracted the attention of people since ancient times.For this reason, among the lands that attracted missionaries, first of all, was Central Asia. Presumably, the spread of Buddhism in this 
region began with the Bactrian kingdom, but until now scientists have not established exactly when this happened.Thus, Indian researchers mark the beginning of the spread of Buddhism from the III (third) Buddhist Cathedral. It took place during the reign of Ashoka (Mauryan dynasty 261-222 BC), known as the defender of Buddhism. At the council, it was decided to preach Buddhism and spread it throughout the world.According to the famous historian E.V. Rtveladze, Buddhism came to Central Asia a little later, during the existence of the Greco-Bactrian Empire. At that time, Buddhism had already taken a strong position in Bactria and the West Indies (Yandharu). Rtveladze's theory is confirmed by numerous archaeological finds on the territory of the ancient Greco-Bactrian kingdom. In particular, coins of the Greco-Bactrian king Agatokles (about 185-170 BC) with the image of a Buddhist "stupa" on them were found here. The famous researcher of Central Asia B. Litvinsky believes that the influence of Buddhism in Bactria can be traced back to the preKushan and early Kushan periods. His point of view is based on historical sources dating from the first century $B C$ to the first century $A D$. e.On the basis of archaeological data from excavations of Buddhist monuments in Northern Bactria, another authoritative historian B. Stavisky suggests that Buddhism was found in Bactria during the reign of the famous Kushan ruler Kanishka (late 1st and early 2 nd centuries AD). -eastern territories in Ancient Bactria, their establishment on these lands and the transition to a sedentary way of life served to create at the end of the 1st century BC. Great Kushan kingdom. As a result of hostilities under the leadership of the Guishuang family, the Yuezhi tribe, consisting of five large families, is united into a single Kushan state. Thus, the creation of the Kushan Empire took place, one of the four great empires of the ancient world. Its borders were in contact from the east with the Chinese empire of Khan, and from the west - with the Parthian empire. At the same time, the Kushan Empire had trade and cultural ties with the Roman Empire.The powerful Kushan state of the ancient world existed for almost 5 centuries, it also included the territories of North India. The Kushan state reached its peak during the reign of the emperor Kanishka.At this time, various spheres of culture and art developed on the lands of Bactria. At the same time, Buddhist teachings penetrate through the Hindykush into the Kushan state,influences the formation of the ideological worldview of the population of Old Termez and plays an important role for almost seven centuries from the 1 st to the 7 th centuries. $n$. e. This is evidenced by the Chinese missionary XuanJian, who visited in the 7th century. n. e. in Ancient Bactria. In his notes, he points out that in Old Termez there are dozens of temples with thousands of priests performing divine services. The results of studies of Buddhist monuments of Ancient Termez provide an opportunity to determine the time and ways of penetration of Buddhism into Central Asia. For the first time Buddhism appears in Old Termez in the 1st century. BC e. and, apparently, is actively promoted among the local populationduring the emergence of the Kushan state. By the reigns of SoterMegas and WimKadfiz, Buddhist societies had an impressive dominant position in the city. Most of the city's aristocrats, 
administrators and their assistants, having studied Buddhism, became its followers. Buddhism reaches its peak in the city in the 2nd - 4th centuries. ad.During the time of the Kushanids, Termez was a large Buddhist center and a place of pilgrimage. It occupies an especially important place in the widespread spread of Buddhism in East Turkestan, China and the Far East.Many Buddhist buildings have been erected on the northwestern border of Termez. Founded here, on an area of 8 hectares, a large Buddhist center, like Karatepa, owns more than thirty temples.Karatepa is a complex of cave temples located in the northeastern part of Old Termez. The monument has been studied for almost 100 years. It was first opened in 1926-1928. Moscow expedition of the State Museum of the Culture of Oriental Peoples.In 1937 it was checked by E.G. Pchelina and M.E. Masson. In the 1960s, excavations carried out by archaeologist B.Ya. Staviskiy gave science a lot of new and accurate information about this mysterious monument.In recent years, effective joint work by the Uzbek-Japanese archaeological expedition has been carried out at this monument. Karatepais considered one of the largest Buddhist structures in the city of Termez 1-4 centuries. AD At one time, a religious center was located on a natural elevation, which is a complex of dozens of original buildings. Each of the buildings consisted of ground and underground premises, including a courtyard surrounded by an open terrace, a temple with circumferential passages and cave cells of the priests. There were small stupas in some courtyards. The Karatepa Temple and its terraces are adorned with imposing color images depicting local and Buddhist legends, in particularimages of people with offerings of gifts to Buddha and Bodhisattva. At the same time, Buddhist figurines made of stone, gakyil and clay, capitals with carved animal heads, many examples of small art, represented by terracotta figurines and various ceramic dishes were found in the temple. An especially important find at Karatepa is the ancient writing system. The first group of writing Karatepa includes inscriptions on ceramic dishes, made in black ink. Many writings contain religious dogmas, performed by the Indian alphabet Kharoshthi and Brahma. In particular, the writings on the ceramics contain information about individuals who bring gifts to the temple.The letters of the second group are graphites. After the temple was abandoned, those who came here left scribbled letters on the walls of the temples. After analyzing the letters written in Farsi, scientists came to the conclusion that with the arrival of Iranian troops on Karatepa, the temples were abandoned and eventually turned into ruins.

In addition to Karatep, more than 100 monuments of the Kushan period have been uncovered and studied in the Surkhandarya region. Of these, Zartepa, Kampirtepa, Dalvarzintepa, Kholchayon, Budrachtepa, Chingiztepa, Ayrit, Fayoztepa and Zurmala, associated with Buddhist culture, are effectively used in the tourism sector. 


\section{Edge}

The study of Buddhism and Buddhist artistic culture in Central Asia began in 1932, when on the territory of Airitom, located $7 \mathrm{~km}$. Above Termez, at the bottom of the Amu Darya, among the leaves of the acanthus, a stone relief was found with the image of three figures of musicians up to the waist, playing the harp, dombra and ude. The find of this frieze served as an impetus for the study of Buddhism and Buddhist artistic culture.In 1933, under the leadership of M.E. Masson, excavations were carried out, during which 7 more fragments of friezes and the ruins of a Buddhist temple were found.Friezes date back to the 1-2 centuries, they depict wreaths of flowers, young men and women with fruits in vessels, musicians playing the kushnai, chiltor, ud and nagora.In 1963-1966, an art criticism expedition of Ubekistan (B. Turgunov) conducted excavations in Ayritom. In 1978, during excavations, the pedestal of the statue was found, on which there was an inscription of six lines in the Greek alphabet. The material and cultural monuments of Ayritom of the Kushan era are of great importance in the study of the history of the Uzbek people, cultural heritage and customs.

The Airritom frieze depicts a scene associated with Parinnirvana-zhataka.

According to Indian legends, the melodious, gentle sounds of five musical instruments should provide the deceased Buddha with peace of mind, and donatrixes should accompany him on his last journey with fragrant flowers. The appearance of the characters in the legendary scene of the Ayritom frieze suggests that they come from the local population.In addition, it is determined that there is a close connection between the Airrit frieze and the Gandhara art. Thus, the widespread assumption of scientists about the existence of the Gandharaschool within the Kushan kingdom was confirmed by the presence of an extraordinary historical cultural reality. Fayoztepa. The monument is located in the northwestern part of Old Termez, it is a rectangular temple-monastery complex, consisting of three parts. The monument was studied in 1968-1976. scientist L.I. Albaum. The name of the monument is associated with the name of one of the organizers of archaeological research, the former director of the local history museum of the Surkhandarya region, R. Fayozov.The monument consists of three parts: in the central part there is a temple, in the north-west - a monastery, in the south-east - outbuildings. The total area of the complex is about 1.5 thousand square meters

In the central part of the complex there are 13 rooms and a courtyard with a terrace. A triad with the image of Buddha and two monks, made of limestone, was found in the monastery, which glorified Fayoztep throughout the world. On the square of the monastery there are premises where monks and novices lived. The monastery has study rooms and halls, as well as rooms for pilgrims who stayed for the night. There are shelves for wicks on the walls of the premises. Statues of Buddha and pedestals for the installation of Buddha statues were found under the walls of some rooms. This means that after the 
end of the religious rituals in the central church, monks, novices and pilgrims performed their prayers in the prayer rooms of the monastery.A large number of utensils with kharoshtha, brahma and Bactrian characters were found in the canteen and utility warehouses located in the south of the complex. On the eastern side of the complex, outside the temple, stands a stupa, which is considered a sacred structure by Buddhists. Active in the 1-3 century AD. temple-monastery in the 4th century AD plundered by the Sassanian troops ended its existence.In 2002, thanks to the support of the regional khakim, the Buddhist temple on Fayoztepa was chosen as an object for conservation and partial restoration by the Ministry of Culture of the Republic of Uzbekistan, the UNESCO office in the Republic of Uzbekistan and the Japan Trust Foundation.

During 2004-2006, for the first time in the history of archaeological sites of Uzbekistan, the planned works were carried out and implemented. As a result, a rare gem - the Fayoztepa temple - became an open-air museum.

\section{Zurmala.}

Among the Buddhist structures, the Zurmala stupa, located in the eastern part of Old Termez, deserves special attention. With a diameter of $14.5 \mathrm{~m}$ and a height of $13 \mathrm{~m}$, the remains of a cylindrical stupa amaze with their grandeur. The tower was built of rectangular bricks.In the upper part, at the transition to the dome, the circle of the brickwork is clearly traced. An archaeological study of the tower showed that the cylindrical part of the Zurmala stupa was built on a rectangular pedestal with sides of $16 \times 22$ meters and a height of $1.4 \mathrm{~m}$. Comparing the stupa with other structures, it can be assumed that the steps leading to the cylindrical part of the stupa were located in the central part of the eastern side of the pedestal ... The presence of stone and limestone blocks, architectural decorations and reliefs next to the monument suggests that the stupa was once covered with stone and relief.Are there any additional structures near the stupa? This can be answered based on the results of scientific research on the study of the stupa by Uzbek archaeologists in conjunction with the Japanese University of Risho. The expected results require further in-depth study of this Buddhist structure, its restoration and conservation in order to fully preserve this unique monument for future generations.Dalvarzintepa. The ruins of the Dalvarzintep monument located in the Shurchinsky district of the Surkhandarya region are considered the first capital of the Kushan state.Dalvarzintepa is located $10 \mathrm{~km}$. northeast of the town of Shurchi. Its area is 47 hectares. The complex was built in two parts: from the royal fortress and the city, which are surrounded by a 10-meter solid wall. The city was inhabited by the elite part of the population (representatives of the royal family), artisans, merchants and religious ministers. There is an assumption that Dalvarzintepa was the first capital of the Kushan kingdom. At the end of the 2nd century-1st centuries BC, a small settlement appeared in 
this place. In the Kushan era, during the reign of Kanishka, Dalvarzintepwas formed as a city. On the territory of northern Bactria by the end of the 1st century BC - at the beginning of our era this city was consideredthe largest of the cities that existed at that time.An art criticism expedition of the Research Institute of Art Criticism of Uzbekistan in 1962 for the first time conducted research at Dalvarzintepa, and since 1967 has been conducting constant archaeological research. It was suggested that the first capital of the Kushan kingdom was located on the site of Dalvarzintep. At the end of the 3rd and the beginning of the 4th century $A D$, after the Hephthalites conquered the Kushan kingdom and the devastation of Dalvarzintep, life was preserved only in one part of it (the modern fortress) - on the site of the royal palace.After the invasion of the Arabs, the city was completely destroyed and life moved about $10 \mathrm{~km}$. east of Dalvarzintep to the place of Budrachtepa.In 1989, a new stage began in the study of Dalvarzintep. The art criticism expedition of Uzbekistan together with the Tokyo Soka University and under the leadership of the professor of the Kashihara Archaeological Institute Kato Kyudzo began research work. Study of Buddhist history in Central Asia, Buddhist characters, iconography, peculiar relations and laws in the process of urban planning, the formation of statehood, traces of the Great Silk Road, the interaction of Kushan religious beliefsperiod and their reflection in the art of Bactria-Tokharistan - were the primary tasks in a number of scientific problems for Uzbek and Japanese scientists. The coin-seal of one of the emperors of the Kushan kingdom, Vim Kadfiz, found here in 2015, served as further material evidence that Dalvarzintepa is the first capital of the Kushan state.

Holchayon is a complex of cultural monuments of the Kushan and Greco-Bactrian eras. This object represents the most ancientruins - Khanakokhtepa, Karabogtepa, Maslakhattepa and others. The remains of such structures as a canal, a palace, various buildings, traces of garden plantings were found here. The palace in Honokokhtepa had a wooden aivan, a living room, a throne room, and various other premises connected by corridors. The foundation of the palace was made of stone, and its well-built walls were made of adobe bricks (1.40-2.30 meters). The walls of the palace have preserved traces of whitewash, they have patterns and drawings. A fragment of the image was found, which shows a young Bactrian youth with hair smoothly combed back, next to him is another youth, apparently belonging to a different ethnic group.The buildings of the complex are decorated with sculptures that were painted with paints made from glue mixed with natural dyes. The images of women and men are masterfully executed (warriors, a ruler talking to someone, scenes of battles). Numerous archaeological finds were found in Holchayon - a hum (a large jug for storing food), a jug, a basin, ceramic dishes, a saber, a dagger, jewelry, gold coins. This object during 1959-1963 was studied by the art history and archaeological expedition of the Institute of Art Criticism under the leadership of G.A. Pugachenkova. Remains of the ruler's palace found on Honakokhtepa(21 centuries BC), G.A. Pugachenkova refers to the leader of one of the Yuezhi tribes, 
Geray. Life on the monument continued until the beginning of the 3rd century. AD, as evidenced by the coins of Vasudev I. Alexandria Oxiana - Kampirtepa. One of the most interesting and outstanding monuments on the territory of Northern Bactria is the settlement of Kampirtepa. Its study was started by Academician of the Academy of Sciences of the Republic of Uzbekistan, Doctor of Historical Sciences, Professor E.V. Rtveladze in 1972 during an archaeological reconnaissance in the Oksa Valley (Amu Darya) and continues to this day. For three decades, this site was studied by a separate detachment of the Uzbekistan Art Criticism Expedition, and in the years of independence, the Takharistan archaeological expedition of the Institute of Art Studies of the Academy of Sciences of the Republic of Uzbekistan, where in the course of stationary research, the upper building horizon of most of the settlement was uncovered.Kampirtepa is a city founded in the 4th century BC. It is located on a high loess terrace on the right bank of the Amu Darya, $30 \mathrm{~km}$ west of the city of Termez and $1.5 \mathrm{~km}$ in the same direction from the Shurob village of the Muzrabad district of the Surkhandarya region. Long-term research of the head of the expedition, academician E.V. Rtveladze, allowed him to determine that the settlement of Kampyrtepa is identified with the ancient Greek ferry "Pandacheyon" (Greek living room)on the right bank of the Zhaikhun (Amu Darya), which was mentioned in the work of the Persian historian of the 15th century. Hafiz-iAbru.

The city consists of two parts: a fortress and another part located from it on the west-east side and is surrounded by a wall. The total length of the wall from west to east is 750 meters, from north to south - 250 meters.The fortress consists of a fortified and unfortified part, with a total area of 4 hectares. In its structure, the citadel and the territory between the citadel and the outer fortress wall are distinguished, occupied by residential buildings and premises designed for different purposes. Paths are laid between the rooms. The citadel is located in the center of the fortress, on the edge of a high terrace facing the Amu Darya,

on the south side, a significant part of it was washed away. From west to east, its length is $150 \mathrm{~m}$, from north to south $-100 \mathrm{~m}$, area - 1.5 hectares. Outside, along the perimeter, the settlement is fortified by a defensive wall $5 \mathrm{~m}$ wide, with attached rectangular battlement towers and a moat more than $10 \mathrm{~m}$ deep.The fortified part of Kampyrtepais mainly occupied by burial structures. This city in the I-II centuries AD underwent its rise and survived three conquests As a result of the archaeological research carried out at the Kampyrtepa settlement, it was established that during the Greco-Bactrian kingdom it functioned not only as a city, but also as a military garrison. And in the Kushan period, the shakhristan of the settlement intensively settled down with residential blocks, divided by streets-galleries, where in the course of the work a large number of objects of material and artistic culture, a rich collection of coins, as well as monuments of writing - Greek, Bactrian, Brahmi and unknown writing were discovered. Among them, the discovery of the oldest Bactrian manuscripts on papyrus is of great importance, which makes them the 
most ancient manuscripts ever found in Central Asia. In addition, unique pieces of art such as terracotta figurines were found on the site.architectural details, ivory items, jewelry made of precious, semiprecious stones and metals, coins minted by the Kushan rulers and other objects that clearly demonstrate the prosperity of handicraft production and trade.

The Great Silk Road played a huge role in the development of the economy and in the flourishing of the cities of the Kushan kingdom. The Great Silk Road, as the largest trade and cultural route, connected South-Eastern Europe, Iraq, the Caucasus, Central Asia with Mongolia and China. And he played a huge role in the development of cities on the territory of Bactria and, in particular, in Kampyrtepa, where the population of the city was engaged in trade, which contributed to the development of new speciesand handicraft technologies and increasing the volume of goods. One of the main types was ceramic production, which reached its peak in the Kushan period. The variety of types of ceramic products increased, the quality of the vessels made increased, and the decoration of ceramic vessels with various types of ornaments began, which was quite important in Kushan Bactria.

Zartepa - the ruins of an ancient city located in the northwest, $26 \mathrm{~km}$. from the city of Termez. In 1951-1952 Zartepawas investigated by archaeologist L.I. Albaum. Zartepa has the shape of a square, the length of the walls is $400 \mathrm{~m}$. The remains of the eastern walls - 6-7 m, western - $4 \mathrm{~m}$. In the northeast of the city there is a square-shaped fortress-mound, it is separated from the shakhristan by a line of defense - a large moat. In 1960-1980 the research was continued by archaeologists V. Zavyalov, K. Sobirov, Sh. Pidaev. During archaeological excavations in the Zartepashakhristan, the remains of residential buildings were discovered and streets were uncovered. Among the finds, the oldest belongs to the 2nd century. BC. and these finds, in particular, figurines depicting Buddhist teachings and Buddhist characters, provide valuable information about the peoples living in these territories, about their religious worldviews and art. Chingiztepa. On the territory of Old Termez at the sites of Small and Big Chingiztep, archaeological research has been carried out for many years by the "Bactria" mission of the joint Uzbekistan-France expedition under the leadership of Sh. Pidaev. On the basis of Chingiztepa's research, it was an integral part of Old Termez, served as a fortified fortress and ensured the safety of trade caravans crossing the Amu Darya and coming to Termez through the Paygambarorol or coming from the northern edges to this city and from here heading to Baktr (Balkh), as well as to others. sides. In the 2013 season, according to the results of excavations, that the defensive system of Chingiztep was built in the 1st century. BC, after the "Big Yuezhi" completely took possession of Greco-Bactria, settled on the Bactrian lands, in particular, in Termez. Summing up, we can trace how through these monuments the Buddhist teaching penetrated into Central Asia, in the era of the GrecoBactrian kingdom the first elements of Buddhism appeared, during the Kushan kingdom the position of Buddhist teaching among the population was strengthened, it became the 
leading religion, its further development, the penetration of Buddhism to East Turkestan, China, to the states of the Far East. For this reason, it will not be an exaggeration to say that today the Surkhandarya region is forBuddhist pilgrims are one of the most revered places of pilgrimage.In the future, the monuments of Karatepa and Fayoztepa on the territory of old Termezwill be united, and it is planned to create a Buddhist alley in this region, as well as develop archaeological tourism in Dalvarzintepa and other monuments.

\section{RECOMMENDED LITERATURE}

1. Sh.R. Pidaev. Buddhism and Buddhist heritage of ancient Uzbekistan. Book-album. Tashkent. "Uzbekistan" 2011

2. Sh.R. Pidaev. Materials for the study of ancient monuments of Northern Bactria. Ancient Bactria. Leningrad. "Science" 1974

3. Sh.R. Pidev. The mysterious Kushanempire. Tashkent. "Fan" 1990

4. T. Annaev. Early medieval settlements of Northern Tokharistan. Tashkent. 1988 year

5. T. Annayev. Monuments to Angora. Tashkent. "Voris" 2014

6.L. Sverchkov. Tokhars are ancient Indo-Europeans in Central Asia. Tashkent. "SMIASIA" 2012

7. VM Masson. Ancient Bactria. Leningrad. "Science" 1974

8. VM Masson. Bactrian antiquities. Leningrad. "Science" 1976

9. T.V. Grek, E.G. Pchelina, B.Ya.Stavisky. Buddhist caves Karatepa in Old Termez. Moscow. "Science" 1964

10. B.Ya.Stavisky. Buddhist caves Karatepa in Old Termez. Moscow. "Science" 1969

11. B.Ya.Stavisky. Buddhist caves Karatepa in Old Termez. Moscow. "Science" 1972

B.Ya.Stavisky. Buddhist caves Karatepa in Old Termez. Moscow. "Science" 1982

13. B.Ya.Stavisky. South of the Iron Gate. Moscow. "Soviet Artist" 1977

14.G.A. Pugachenkova, E.V. Rtveladze, L.I. Rempel. Dalverzintepe is a Kushan city in the south of Uzbekistan. Tashkent. "Fan" 1978

15.G.A. Pugachenkova. From the history of ancient culture of Uzbekistan. Tashkent. "Literature and Art. GafurGulyam "1973

16. B. A. Litvinsky, A. V. Sedov. Cults and rituals of the Kusha Bactria. Moscow. "Science" 1984

17. E.V. Rtveladze. Materials of the Tokharistan expedition. Archaeological research in Kampyrtep. Issue 2. Tashkent. "Sanat" 2001

18. E.V. Rtveladze. Materials of the Tokharistan expedition. Archaeological research in Kampyrtep. Issue 3. Tashkent. "Sanat" 2002

19. E.V. Rtveladze. Alexander the Great in Bactria and Sogdiana. Tashkent. "Media Land" 2002 


\section{THE AMERICAN JOURNAL OF APPLIED SCIENCES}

ISSN (e): 2689-0992

DOI: https://doi.org/10.37547/tajas/Volume02Issue07-14

20.K.Abdullaev, T.Annaev. Excavations at the Zartepa site in 1979-1981 // IMKU. Issue 23. Tashkent. 1990 year 